Thomas G. Mezger

\title{
The Rheology Handbook
}

For users of rotational and oscillatory rheometers

$5^{\text {th }}$ Revised Edition 
Bibliographische Information der Deutschen Bibliothek Die Deutsche Bibliothek verzeichnet diese Publikation in der Deutschen Nationalbibliographie; detaillierte bibliographische Daten sind im Internet über http://dnb.ddb.de abrufbar.

Mezger, Thomas G.

The Rheology Handbook, $5^{\text {th }}$ Revised Edition

Hanover: Vincentz Network, 2020

European Coatings Library

(C) 2020 Vincentz Network GmbH \& Co. KG, Hanover

Vincentz Network GmbH \& Co. KG, Plathnerstr. 4c, 30175 Hanover, Germany This work is copyrighted, including the individual contributions and figures. Any usage outside the strict limits of copyright law without the consent of the publisher is prohibited and punishable by law. This especially pertains to reproduction, translation, microfilming and the storage and processing in electronic systems.

The information on formulations is based on testing performed to the best of our knowledge.

Please ask for our book catalogue

Vincentz Network, Plathnerstr. 4c, 30175 Hanover, Germany

T+49 511 9910-033, F+49511 9910-029

books@european-coatings.com, www.european-coatings.com

Layout: Vincentz Network, Hanover, Germany

Printed by: Buchdruck Zentrum, Prüm 
European Coatings Library

Thomas G. Mezger

\section{The Rheology Handbook}

For users of rotational and oscillatory rheometers

$5^{\text {th }}$ Revised Edition 